\title{
養豚飼料へのリンゴジュース粕添加による 尿中窒素排泄量の低減
}

\author{
山本朱美・青木幸尚 ${ }^{1)} \cdot$ 伊藤 稔・石川雄治 ${ }^{*}$ \\ 山内克彦 ${ }^{* *} \cdot$ 山田未知 ${ }^{* *} \cdot$ 古谷 修
}

(財)畜産環境整備機構畜産環境技術研究所, 福島県西郷村 961-8061

1)現所属 : 近畿大学生物理工学部, 和歌山県那賀郡打田町, 649-6493

* 福島県畜産試験場, 福島市 960-2156

** 福島県立農業短期大学校, 福島県矢吹町 969-0292

（2001 年 5 月 29 日受付， 2001 年 9 月 19 日受理）

\begin{abstract}
要 約 養豚飼料へのリンゴジュース粕の添加が尿中窒素排泄量に及ぼす影響について 検討した。開始時体重が約 $40 \mathrm{~kg}$ の去勢雄豚 8 頭を供試し，4 頭には CP15.8\%のトウモロ コシとダイズ粕を主体とする標準的飼料を体重の $3 \%$ 給与し（標準飼料区），他の 4 頭には 同量の標準飼料ととあに乾燥リンゴジュース粕を体重の $0.9 \%$ の割合で添加して給与した (リンゴ粕区)。豚は代謝ケージに収容し，9 日間の予備試験の後，5 日間にわたって全量の 糞尿を採取して窒素出納を調べた。1 日当たりの窒素摂取量は標準飼料区およびリンゴ粕 区で，それぞれ，31.9 および $35.3 \mathrm{~g}$ であった。尿中窒素排泄量は，それぞれ，16.8および $10.7 \mathrm{~g}$ とリンゴ粕区で $36 \%$ 低くなった $(\mathrm{P}<0.01)$ が，逆に，糞中窒素排泄量は，それぞれ， 5.3 および $10.9 \mathrm{~g}$ とリンゴ粕区で多くなった $(\mathrm{P}<0.01)$ 。総窒素排泄量は，それぞれ，22.1 お よび $21.6 \mathrm{~g}$ で差が認められなかった。
\end{abstract}

\section{緒 言}

家畜から排出される窒素やリンなどの物質によ る環境負荷の軽減が大きな課題になっている。と くに, 窒素の場合は尿への排出量が多く, 環境へ の負荷を与えるとともに悪臭物質の一つであるア ンモニア発生の原因となるため，これの低減がき わめて重要である。そこで, 栄養的制御によって,
環境負荷物質である窒素の排泄量そのものを減ら す多くの試みがみられるようになった"1)。このう ち，窒素の排泄量については，低 CP 飼料に不足 するアミノ酸を添加して給与することによって， 豚の生産性を損なわずに窒素の排泄量を 30 $45 \%$ 減少させ得ることが明らかにされてお $り^{2 \sim 6)}$, この技術はすでに養豚の現場で実証, 普及 されつつある7)。

Effect of Dietary Addition of Dried Apple Pomace on the Nitrogen Excretion in Urine and Feces of Growing Pigs

A. Yamamoto, Y. Aoki ${ }^{1)}$, M. Itoh, Y. Ishikawa*, Y. Yamauchi**, M. Yamada** and S. Furuya Livestock Industry's Environmental Improvement Organization, Institute of Livestock Industry's Environmental Technology, Nishigo, Fukushima, 961-8061

1) Present address: Department of Biotechnological Science, The School of BiologyOriented Science and Technology, Kinki University, Wakayama, 649-6493

*Fukushima Prefectural Livestock Experiment Station, Fukushima-shi, Fukushima, 9602156

**Fukushima Prefectural Agricultural Junior College, Yabuki, Fukushima, 969-0292 
一方, $\mathrm{CANH}_{\mathrm{AN}}$ et l. $^{8)}$ は， ビートパルプのような 非澱粉多糖類 (non-starch polysaccharide, NSP）を多く含む飼料を給与すると尿中への窒素 排泄量が減少し, 逆に糞中への窒素排泄量が増え ることを明らかにしている。これは, NSP が多量 に大腸に流入することによりそれをエネルギー源 として腸内細菌の増殖が活発になるが，その際に タンパク質合成の窒素源として尿素循環9により 消化管に分泌される尿素が使われるためである。

リンゴジュース粕の大部分はNSP で, 化学的 組成はビートパルプに類似している ${ }^{10)}$ 。そこで, CANH et $a l .^{8)}$ の成績と同様に, リンゴジュース粕 にも尿中窒素排泄量の低減効果があるあのと考え て, 一般的飼料に配合して豚に給与し, 尿中窒素 排泄量が著しく低減されることを見出したので報 告する。

\section{材料および方法}

\section{1. 供試飼料および試験豚の飼育条件}

供試飼料はトウモロコシとダイズ粕を主体とし た飼料（標準飼料）およびこれに乾燥したリンゴ ジュース粕を $30 \%$ 配合 (リンゴ粕飼料)した 2 種 類で，標準飼料の配合割合を表 1 に示した。

同一試験設計の 2 回の実験に, 体重約 $40 \mathrm{~kg}$ の 去勢雄豚 (LWD) 計 8 頭を供試した。1 回の実験 は 7 日間の馴致期間に続く連続した 2 試験期間 （各 14 日間）からなり，4頭の豚を用いて実験を 行った。馴致期間中は, 個別に代謝ケージに収容 した 4 頭の豚すべてに体重の $3 \%$ 量に相当する量 の標準飼料を給与した。これに続く試験期間に, 豚を 2 頭ずつ標準飼料区あるいはリンゴ粕区に割 り当てた。試験開始時の体重に基づき, 標準飼料 区では標準飼料を体重の $3 \%$ に相当する量を, リ ンゴ粕区では体重の $3 \%$ 量の標準飼料に加えてリ ンゴジュース粕を体重の $0.9 \%$ に相当する量を朝 1 回給与した。飲水は自由とした。1 試験期間は 14 日間で，9 日間の予備試験期と 5 日間の䔬尿採 取期からなり， 2 期目には試験飼料を反転給与し て, 1 回の実験で 2 回窒素出納試験を実施した。 したがって， 1 飼料区で 8 頭の豚の窒素出納成績 が得られた。なお，2回目の実験では, 乾物消化率 あ測定した。
表 1. 標準飼料の配合割合（\%)

\begin{tabular}{lr}
\hline \hline トゥモロコシ & 69.80 \\
フスマ & 3.00 \\
脱脂米ヌカ & 3.00 \\
ダイズ粕 & 19.71 \\
動物性油脂 & 2.00 \\
炭酸カルシウム & 1.20 \\
第3リン酸カルシウム & 0.60 \\
食塩 & 0.28 \\
塩化コリン(50\%) & 0.07 \\
DLーメチオニン & 0.03 \\
塩酸 Lーリジン & 0.11 \\
ビタミン・ミネラル混合物 ${ }^{1)}$ & 0.20 \\
\hline
\end{tabular}

1)飼料 $1 \mathrm{~kg}$ 中含量 : ビタミン A 7,140IU, ビタ ミン $\mathrm{D}_{3} \quad 1,428 \mathrm{IU}$, 酢酸 DL- $\alpha$ トコフェロール $4.7 \mathrm{mg}$, メナジオン亜硫酸ナトリウム $5.3 \mathrm{mg}$, 硝酸チアミン $0.17 \mathrm{mg}$, リボフラビン $1.58 \mathrm{mg}$, 塩酸ピリドキシン $0.17 \mathrm{mg}$, シアノコバラミン $15.1 \mu \mathrm{g}$, ニコチン酸アミド $6.2 \mathrm{mg}, \mathrm{D}-$ パント テン酸 $9.8 \mathrm{mg}$, 葉酸 $0.52 \mathrm{mg}, \mathrm{d}$ - ビオチン 35 $\mu \mathrm{g}, \quad$ Mn $15.98 \mathrm{mg}, \quad \mathrm{Fe} 267.66 \mathrm{mg}, \quad \mathrm{Cu} 9.81$ $\mathrm{mg}$, Zn $49.74 \mathrm{mg}$, Co $1.12 \mathrm{mg}$, I $0.24 \mathrm{mg}$

\section{2. 䔬および尿の処理, 化学分析および統計 処理}

窒素出納試験の期間中に排泄された糞および尿 は毎日全量を集めて重量を測定し, そのうちの $1 / 10$ 量を分析用試料として $4^{\circ} \mathrm{C} て ゙$ 保存した。 5 日 間の糞および尿はそれぞれ混合して分析試料とし たが, 粪の場合は通風乾燥機により $60^{\circ} \mathrm{C}$ で乾燥 後, 風乾状態に戻してから, ウィレー粉砕機によ り粉砕した。

飼料, 粪の風乾試料および尿の窒素濃度の分析

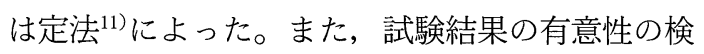
定は繰り返しのある二元配置による分散分析 ${ }^{2)}$ で 行った。

\section{結果および考察}

標準飼料およびリンゴ粕飼料の CP 含量は，そ れぞれ，15.8 および $13.2 \%$ であった。また，リン ゴジュース粕そのあのの CP 含量は $4.61 \%$ で, 飼 料成分表 ${ }^{10)}$ の $8.5 \%$ Ewing ${ }^{13)}$ の 7.0\%より屯少 
表 2. リンゴジュース粕の添加が窒素排泄量に及ぼす影響1

\begin{tabular}{lccc}
\hline \hline & 標準飼料 & リンゴ粕飼料 & SE \\
\hline 飼料摄取量 $(\mathrm{kg} / \mathrm{d})$ & 1.26 & $1.67(133)^{* *}$ & 0.04 \\
窒素䝮取量 $(\mathrm{g} / \mathrm{d})$ & 31.9 & $35.3(110)^{*}$ & 1.0 \\
粪中窒素排泄量 $(\mathrm{g} / \mathrm{d})$ & 5.3 & $10.9(204)^{* *}$ & 0.3 \\
尿中窒素排泄量 $(\mathrm{g} / \mathrm{d})$ & 16.8 & $10.7(64)^{* *}$ & 0.8 \\
総窒素排泄量 $(\mathrm{g} / \mathrm{d})$ & 22.1 & $21.6(98)$ & 0.7 \\
\hline
\end{tabular}

1) 各飼料で 8 頭の平均値，（）は標準飼料に対する相対值

${ }^{* *} \mathrm{P}<0.01, \quad{ }^{*} \mathrm{P}<0.05$

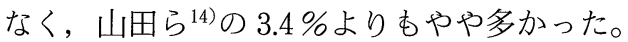

標準飼料とリンゴ粕飼料を肥育豚に給与した場 合の飼料摂取量および窒素出納を表 2 に示した。 試験期間中は全ての個体で残飼は認めらず，飼料 摂取量はリンゴ粕飼料区で約 $30 \%$ 多くなった。 窒素摂取量は飼料摂取量が多い分, リンゴ粕飼料 給与で高くなったが，その差は約 10\% であった。 1 日当たりの総窒素排泄量は標準飼料区で $22.1 \mathrm{~g}$, リンゴ粕飼料区で $21.6 \mathrm{~g}$ ととんど差はなかっ た。しかしながら, 尿中窒素排泄量はリンゴ ジュース粕の添加により，標準飼料を給与した場 合に比べ $64 \%$ にまで減少した。逆に糞中窒素排 泄量はリンゴジュース粕の添加により, 約 2 倍に 増加した。

表 3 に各供試飼料およびリンゴジュース粕その あのの乾物および見かけの $\mathrm{CP}$ 消化率を示した。 なお，リンゴジュース粕の消化率は，標準飼料に リンゴジュース粕を添加しても標準飼料の消化率 は変わらないとの前提で算出した。見かけの $\mathrm{CP}$ 消化率は，標準飼料の $83.3 \%$ に対してリンゴ粕飼 料では $68.9 \%$ と低くなり, リンゴジュース粕その あのの CP 消化率は-106.1\% と大幅にマイナスと なった。飼料成分表 ${ }^{10)}$ では CP の消化率をゼロと している。2 期目に実施した乾物消化率では，リ ンゴジュース粕そのむのは 4 頭の平均值で $58.7 \%$ となり，CP 消化率に比較して高かった。リンゴ ジュース粕の消化率は, 可溶無窒素物 $58 \%$, 粗繊 維 $48 \%$ とされており ${ }^{10)}$ ，ここで得られた乾物消 化率はほぼ妥当な值と考えられる。リンゴジュー ス粕の澱粉および糖の含量はそれぞれ，2 および 15\% と少なく ${ }^{13)}$ ，炭水化物のほとんどが NSP で
表 3. リンゴジュース粕の添加が乾物および見 かけの CP 消化率に及ぼす影響

\begin{tabular}{lrr}
\hline \hline & \multicolumn{2}{c}{ 消化率 $(\%)^{1)}$} \\
\cline { 2 - 3 } & \multicolumn{1}{c}{ 乾物 } & \multicolumn{1}{c}{$\mathrm{CP}$} \\
\hline 標準飼料 & $83.0 \pm 1.9$ & $83.3 \pm 1.5$ \\
リンゴ粕飼料 & $77.4 \pm 1.1$ & $68.9 \pm 2.2$ \\
リンゴジュース粕 & $58.7 \pm 4.7$ & $-106.1 \pm 25.3$ \\
\hline 1)乾物消化率は 4 頭, $\mathrm{CP}$ 消化率は 8 頭の平均 \\
值士標準偏差
\end{tabular}

あるため, 消化されたものの大部分は菌体タンパ ク質合成のエネルギーとして使われたものと考え られる。

CANH et al. ${ }^{8)}$ は, ビートパルプのような NSP を多く含む飼料を給与すると尿中への窒素排泄量 が減少し，逆に粪中への窒素排泄量が増えること を明らかにしている。これは，NSP が多量に大腸 に流入することによりそれをエネルギー源として 腸内細菌の繁殖が活発になるが，その際にタンパ ク質合成の窒素源として尿素循環9 により消化管 に分泌される尿素が使われるためであるとされて いる。リンゴジュース粕の化学的組成はビートパ ルプに類似してお抢り ${ }^{10)}$, CANH et al. ${ }^{8)}$ のビートパ ルプ，ダイズ皮等の NSP を多量に含む飼料原料 を用いた成績と同様に，リンゴジュース粕にも尿 窒素排泄量の低減効果があることが確かめられ た。本試験では，体重維持に近い制限給䭒を行っ ており, 不断給餌であ同様の効果があるか否かは 明らかではないが， CANH et al. ${ }^{8)}$ は不断給餌に近 い条件でビートパルプを用いて実験を行い, 窒素 
の排泄経路が尿から粪に明確に移行することを観 察している。したがって, 本試験で用いたリンゴ ジュース粕の添加飼料の場合でも，不断給餌に近 い条件で同様の効果があると考えられる。

NSP の給与によって糞中に増える窒素の大部 分は菌体タンパク質と考えてよ( ${ }^{8)}$ 。この窒素は 直接飼料の不消化物に由来するあのではなく，い わゆる糞中代謝性窒素である。リンゴ粕飼料の給 与によって CP の見かけの消化率が大幅に負に なったのはこの代謝性窒素の増加に起因してい る。

CANH et al. ${ }^{15)}$ は， 飼料中の NSP 含量を増加さ せると粪と尿の混合物からのアンモニア発生量が 直線的に低下することを報告している。これは, NSP の給与によって尿中への窒素排泄量が減る ことによっている。豚の尿中の窒素化合物のうち 約 $97 \%$ が尿素の形態で存在する ${ }^{16)}$ が， アンモニ アの発生は，この尿中の尿素が䔬中に含まれる尿 素分解酵素であるウレアーゼと反応する結果であ $3^{17)}$ 。山本 $丂^{5)}$ む, 低 CP 飼料の給与により尿中窒 素排泄量ととあに糞尿混合物加らのアンモ二ア発 生量が著しく減ることを報告している。本研究に おいて，一般的な標準飼料へのリンゴジュース粕 の $30 \%$ の添加により, 尿中への窒素排泄量が $36 \%$ 低減されることが明らかになったが，アンモ ニア発生量への影響についての実証は今後の課題 である。鈴木らはリンゴジュース粕を $10 \%$ 添加 した飼料で肥育試験を行い，発育および飼料の利 用性はやや劣ったが，養豚飼料原料として十分に 利用できると報告している18)。また，山田らは， 同じくリンゴジュース粕 $10 \%$ 添加で, 発育之肉 質を調べているが，発育には差がなく，脂肪軟化 を防ぐ可能性を示唆している ${ }^{14)}$ 。発育や肉質につ いてはさらなる検討が必要であろう。

\section{文献}

1）斎藤 守：ニワトリおよびブタからの環境 負荷物質の低减化に関する栄養飼料学的研 究の動向, 日畜会報, 72, J177-J199, 2001.

2）古谷 修 - 渡部正樹 - 阿部博行 - 清水俊 郎・大門博之・佐藤圭子・今田哲雄・佐藤 金一: アミノ酸添加低蛋白質飼料の給与に よる肉豚に打ける窒素排泄量の低減，日豚
会誌, 34, 15-21, 1997.

3) Tachibana, F., and H.Ubagai : Effect of reducing crude protein and energy content in diets with amino acid supplementation on nitrogen balance, performance and carcass caracteristics in pigs, Anim.Sci.Technol.(Jpn.), 68, 640649, 1997.

4) Suzuki, K., X.C.Cheng, H.Kano, T.Shimizu and Y.SATO: Influence of low protein diets on water intake and urine and nitrogen excretion in growing pigs, Anim.Sci. Technol.(Jpn.), 69, 267-270, 1998.

5）山本朱美・高橋栄二・古川智子・伊藤 稔・石川雄治・山内克彦・山田未知・古谷 修: 肉豚へのアミノ酸添加低タンパク質飼 料の給与による尿量, 窒素排泄量およびア ンモニア発生量の低減効果, 日豚会誌，39, 20-26, 2002.

6）農林水産省農林水産技術会議事務局編：日 本飼養標準 ・豚 (1998版), 中央畜産会, 1998.

7）高木久雄 - 花積三千人 - 風早祐次 - 池田卓 夫 ・ 山崎廣明 - 米持千里 : 肉豚の肥育期に おける窒素排泄量の低減に関する検討, 平 成 10 年度流通飼料畜産環境改善機能高度 化推進事業報告書, 3-47, (社) 日本科学飼料 協会, 東京, 1999 .

8) Canh, T.T., M.W.A.Verstegen, A.J.A. AARNINK and J.W.SCHRAMA : Influence of dietary factors on nitrogen partitioning and composition of urine and feces of fattening pigs, J.Anim.Sci., 75, 700-706, 1997.

9) Mosenthin, W.C., H.Sauer, H.Henkel, F. Ahrens and C.F.M.de LANGE: Tracer studies of urea kinetics in growing pigs : II. The effect of starch infusion at the distal ileum on urea recycling and bacterial nitrogen excretion, J.Anim.Sci., 70, 3467-3472, 1992.

10）農林水産省農林水産技術会議事務局編：日 本標準飼料成分表 (1995 年版), 中央畜産 会, 1995.

11）森本 宏 (監修)：動物栄養試験法, 養賢 堂, 東京, 1971.

12）吉田 実: 畜産を中心とする実験計画法, 養賢堂, 東京, 1975. 
13) Ewing, W.N. : The Feeds Directory, Vol. 1, Empress Publishing Netherlands, The Netherlands, 2000.

14）山田未知 - 相楽朝美 - 小山有子 - 金澤 忍・山田幸二・山内克彦 : 乾燥リンゴ ジュース粕給与による飼育豚の発育性掞よ び脂肪組織と筋肉の脂肪酸組成への影響に ついて, 福島農短大研報, (9), 1-5， 2001.

15) Canh, T.T., A.L.Sutton, A.J.A.Aarnink, M.W.A.VERSTEGEN, J.W.SChrama and G. C.M.BAKKER : Dietary carbohydrates alter the fecal composition and $\mathrm{pH}$ and the ammonia emission from slurry of growing pigs, J.Anim.Sci., 76, 1887-1895, 1998.

16) Schulte, D.D. : Critical parameters for emissions. In Proceedings of the international symposium: Ammonia and odour control from animal production facilities, eds. J.A.M. Voermans and G.J. Monteny, 23-34, Vinkeloord, The Netherlands, 1997.

17) Aarnink, A.J.A., P.Hoeksma and E.N.J. VAN OUWERKERK : Factors affecting ammonium concentration in slurry from fattening pigs. In Proceedings of the Congress on Nitrogen Flow in Pig Production and Environmental Consequences, eds. M.W.A.Verstegen, L.A.den Hartog, G.J.M.van Kempen and J.H.M. Metz, 413-420, Pudoc, Wageningen, 1993.

18）鈴木義邦 - 杉本忠宏 - 高橋敏能 - 加藤剛 夫：リンゴ搾汁乾燥粕の豚用飼料原料とし ての利用について，日豚会誌，29， 107， 1992. 


\title{
Effect of Dietary Addition of Dried Apple Pomace on the Nitrogen Excretion in Urine and Feces of Growing Pigs
}

\author{
Akemi Yamamoto, Yukihisa Aoki ${ }^{1)}$, Minoru Itoh, Yuji Ishikawa*, \\ Yoshihiko Yamauchi**, Michi Yamada** and Shu Furuya
}

Livestock Industry's Environmental Improvement Organization, Institute of Livestock Industry's Environmental Technology, Nishigo, Fukushima, 961-8061

1) Present address : Department of Biotechnological Science, The School of Biology-

Oriented Science and Technology, Kinki University, Wakayama, 649-6493

* Fukushima Prefectural Livestock Experiment Station, Fukushima-shi, Fukushima, 960-2156

** Fukushima Prefectural Agricultural Junior College, Yabuki, Fukushima, 969-0292

We investigated the effects of addition of dried apple pomace to a corn-soybean meal-based diet (standard diet) on the fecal and urinary nitrogen excretion in growing pigs. Eight barrows (BW approximately $40 \mathrm{~kg}$ ) were allotted to two treatments of four pigs each, in which the standard diet or the diet supplemented with $30 \%$ of dried apple pomace to the standard diet was given. The pigs were placed individually in the metabolism cages. After a 9-d pre-experimental period, urine and feces were quantitatively collected daily, for a 5 -d period. The pigs fed the dried apple pomace-supplemented diet excreted 36\% less nitrogen in urine and 104\% more nitrogen in feces than the pigs fed the standard diet. However, the total nitrogen excretion was not affected by the dried apple pomace supplementation to the standard diet $(\mathrm{P}>0.05)$. Apparent $\mathrm{CP}$ digestibility of the dried apple pomace was $-106.1 \%$.

Jpn. J. Swine Science, 39, $1: 8-13$

Key words : Pigs, Apple pomace, Diet, Nitrogen balance, Excreta 